\title{
Clozapine-Related Thromboembolic Events
}

Elisa Pallares Vela ${ }^{1}$, Prashil Dave ${ }^{2}$, Ivan Cancarevic ${ }^{3}$

1. General Medicine, California Institute of Behavioral Neurosciences \& Psychology, Fairfield, USA 2. General Practice, California Institute of Behavioral Neurosciences \& Psychology, Fairfield, USA 3. Internal Medicine, California Institute of Behavioral Neurosciences \& Psychology, Fairfield, USA

Corresponding author: Elisa Pallares Vela, elisa014_@hotmail.com

\begin{abstract}
Clozapine is an atypical antipsychotic used for treatment-resistant schizophrenia. Venous thromboembolism (VTE) is a rare side effect of clozapine which can be fatal. This article summarizes current evidence regarding the risk of VTE associated with the use of clozapine. We performed a PubMed (MeSH) and Google Scholar search for the last two decades. Studies or case reports performed in humans were included in the review, of which 42 case reports of patients taking clozapine at VTE onset were included in the analysis of this review. According to the articles reviewed, the mean age was 42.9 years, with more males (71.43\%) than females (28.57\%). The average clozapine dose was $285.62 \mathrm{mg} /$ day. VTE onset occurred within the first six months in $71.8 \%$ of the cases. Overall, $70.37 \%$ of the patients had comorbidities, and $87.5 \%$ had risk factors for VTE. In total, $68.57 \%$ were prescribed other medications at VTE onset, and $60 \%$ were being treated with another antipsychotic concomitantly. Finally, $32.5 \%$ of the patients died, while $67.5 \%$ survived. In $60 \%$ of the cases, clozapine was discontinued after VTE. In our literature review, we observed that among clozapine users, VTE occurred at a wide dose range, and most of the events occurred within the first six months. As many patients who are prescribed clozapine have risk factors for VTE, the risk should be considered at the time of prescribing. Further research should be conducted to elucidate the risk of VTE in clozapine users and the benefits of thromboprophylaxis.
\end{abstract}

Received 06/21/2021

Review began $07 / 17 / 2021$ Review ended 07/25/2021 Published 08/04/2021

$\odot$ Copyright 2021

Pallares Vela et al. This is an open access article distributed under the terms of the Creative Commons Attribution License CC-BY 4.0., which permits unrestricted use, distribution, and reproduction in any medium, provided the original author and source are credited.
Categories: Internal Medicine, Psychiatry, Pulmonology

Keywords: clozapine, antipsychotics, atypical antipsychotics, pulmonary embolism, venous thrombosis, thrombosis, thrombotic events

\section{Introduction And Background}

Schizophrenia is a mental disorder that affects approximately 20 million people worldwide [1]. Despite its low prevalence, schizophrenia is a severe mental illness that may profoundly impact the individual [1]. It is a disease with complex genetics and not well-elucidated pathophysiology where environmental factors may play an important role [2]. Studies are constantly being conducted to further understand this mental disorder.

Pharmacological and nonpharmacological therapies are available and can be beneficial. Antipsychotics, both typical and atypical, have been widely used for the treatment of this disorder [2]. Atypical antipsychotics have been found to have a better safety profile when talking about neurological side effects than typical antipsychotics; nevertheless, no significant differences have been observed regarding the effectiveness of the treatment of positive symptoms [2]. The choice of long-term therapy depends upon the prior history of response and the avoidance of side effects [2].

For patients who have refractory schizophrenia, clozapine, an atypical antipsychotic, is the preferred treatment pathway $[2,3]$ and has shown better response rates than other drugs $[2,3]$. Clozapine is a dibenzodiazepine that interacts with different subtypes of dopaminergic, serotoninergic, adrenergic, histaminergic, and muscarinic receptors [4]. Apart from presenting fewer neurological side effects, it has been observed to reduce mortality rates for suicide in patients with schizophrenia [4]. In contrast, there are many adverse effects, with one of the rare ones being pulmonary embolism (PE) [4]. PE contributes to increased mortality in patients prescribed clozapine [4].

Venous thromboembolism (VTE) is a multifactorial disease that encircles PE and deep vein thrombosis (DVT) and is one of the three leading causes of death from cardiovascular diseases [5,6]. It is estimated that there are 100,000 to 180,000 deaths annually in the United States due to PE, and it is the most common preventable cause of death among hospitalized patients [7]. Well-described risk factors for VTE include major surgery (general or orthopedic), lower extremity paralysis, lower extremity fractures, multiple trauma, cancer, prior VTE, age (>40 years), obesity, immobility, oral contraceptives or estrogen treatment, pregnancy or postpartum, genetic blood conditions, sedentarism, and family history to VTE, among others [8].

Thrombotic events have been observed in patients taking clozapine [3,4]. However, there is insufficient evidence to hold clozapine accountable for thrombotic events or to know if VTE develops as a consequence of weight gain and sedation, and if it is positively correlated with PE $[3,4]$.

Despite existing research, it remains unclear whether clozapine treatment causes thrombotic events to occu or if the disease itself puts these patients at a higher risk of developing thrombotic events. The mechanisms underlying the development of thrombotic events in schizophrenic patients and those taking clozapine are not yet elucidated. This study aims to perform a literature review of the latest evidence and case reports intending to unearth the relationship between clozapine and thrombotic events.

\section{Methodology}

We performed a comprehensive PubMed (MeSH) and Google Scholar search for the last two decades. We used the keywords "clozapine," "antipsychotics," or "atypical antipsychotics" and combined them using the Boolean operator "and" with the words "pulmonary embolism," "venous thrombosis," "vein thrombosis," "thrombosis," or "thrombotic events." We included human-only studies or case reports with an available 
abstract or a full-text article in English, Spanish, or French languages. Only case reports of patients who were taking clozapine at the onset of VTE were included. We excluded articles or case reports that did not meet these criteria. Overall, we found 42 case reports published in the last two decades.

\section{Review}

VTE is a rare adverse event associated with clozapine use [4,9]. There is consistent evidence with regards to a higher risk of VTE among patients prescribed clozapine, namely, between three-fold and 27.5-fold risk of VTE compared to the general population $[6,10]$. According to Sackey et al., PE is the second leading cause of death after external factors such as accidents or suicide [11]. A study of the World Health Organization database from 79 countries on adverse drug reactions showed 754 cases of VTE during antipsychotic treatment, out of which approximately 375 were related to clozapine use [12]. This review included a total of 42 case reports published in the last two decades (Table 1) [10-13,26-49]. We included cases of clozapine users who developed VTE including PE and DVT.

\begin{tabular}{|c|c|c|c|c|c|c|c|c|c|c|c|}
\hline $\begin{array}{l}\text { Reference } \\
\text { number }\end{array}$ & $\begin{array}{l}\text { Publication } \\
\text { year }\end{array}$ & Author & Age & Sex & $\begin{array}{l}\text { Dose } \\
\text { (mg/day) }\end{array}$ & $\begin{array}{l}\text { Treatment } \\
\text { duration }\end{array}$ & Outcome & $\begin{array}{l}\text { Risk } \\
\text { factors } \\
\text { for } \\
\text { VTE }\end{array}$ & $\begin{array}{l}\text { Clozapine } \\
\text { discontinuation }\end{array}$ & Comorbidities & $\begin{array}{l}\text { Additional medication at VTE } \\
\text { onset }\end{array}$ \\
\hline [10] & 2018 & $\begin{array}{l}\text { Tseng and } \\
\text { Huang }\end{array}$ & 41 & Male & 175 & 24 months & Survived & Yes & No & $\begin{array}{l}\text { Obese (BMI } 39 \\
\mathrm{~kg} / \mathrm{m}^{2} \text { ) }\end{array}$ & Lithium \\
\hline [11] & 2017 & Sackey et al. & 60 & Male & 500 & 3 days & Survived & Yes & No & $\begin{array}{l}\text { Transient } \\
\text { ischemic } \\
\text { attacks, } \mathrm{HT} \text {, } \\
\text { hypothyroidism }\end{array}$ & No \\
\hline [12] & 2000 & Hägg et al. & 59 & Male & 300 & 14 days & Death & Yes & - & NA & Phenoxymethylpenicillin \\
\hline [12] & 2000 & Hägg et al. & 26 & Male & 500 & 20 months & Death & NA & - & NA & Cyproterone acetate \\
\hline [12] & 2000 & Hägg et al. & 38 & Female & 150 & 14 days & Death & NA & - & NA & Haloperidol \\
\hline [12] & 2000 & Hägg et al. & 53 & Male & 100 & NA & Death & Yes & - & NA & Clomipramine \\
\hline [12] & 2000 & Hägg et al. & 33 & Male & 200 & 3 months & Death & NA & - & NA & Lactulose, propantheline \\
\hline [12] & 2000 & Hägg et al. & 36 & Male & 200 & 3 months & Survived & NA & NA & NA & Erythromycin \\
\hline [12] & 2000 & Hägg et al. & 54 & Male & 500 & 15 days & Survived & Yes & NA & NA & $\begin{array}{l}\text { Perphenazine, } \\
\text { levomepromazine, amitriptyline }\end{array}$ \\
\hline [12] & 2000 & Hägg et al. & 29 & Male & 400 & 21 days & Survived & NA & NA & NA & Clonazepam, carbamazepine \\
\hline [12] & 2000 & Hägg et al. & 30 & Male & 200 & 3 months & NA & NA & NA & NA & $\begin{array}{l}\text { Carbamazepine, orphenadrine, } \\
\text { thioridazine }\end{array}$ \\
\hline [12] & 2000 & Hägg et al. & 25 & Female & 400 & NA & Survived & Yes & NA & NA & $\begin{array}{l}\text { Levonorgestrel/ethinyloestrdiol, } \\
\text { diazepam, terbutaline, } \\
\text { budesonide }\end{array}$ \\
\hline [12] & 2000 & Hägg et al. & 42 & Male & 75 & 24 months & Survived & Yes & NA & NA & $\begin{array}{l}\text { Biperiden, flupentixol, } \\
\text { lorazepam, clomipramine }\end{array}$ \\
\hline [13] & 2016 & Gami et al. & 40 & Male & 350 & $\begin{array}{l}6.42 \\
\text { months }\end{array}$ & Death & Yes & - & $\begin{array}{l}\text { Chronic knee } \\
\text { pain }\end{array}$ & Omeprazole, ibuprophen \\
\hline [26] & 2000 & $\begin{array}{l}\text { Coodin and } \\
\text { Ballegeer }\end{array}$ & 30 & Male & 150 & 12 days & Survived & NA & Yes & NA & NA \\
\hline [27] & 2000 & $\begin{array}{l}\text { Suttmann et } \\
\text { al. }\end{array}$ & 33 & Female & 250 & 12 days & Survived & Yes & Yes & $\begin{array}{l}\text { Factor V Leiden } \\
\text { mutation }\end{array}$ & NA \\
\hline [28] & 2000 & Maynes & 30 & Male & 400 & 5 months & Survived & NA & Yes & NA & NA \\
\hline [29] & 2001 & $\begin{array}{l}\text { Ihde-Scholl et } \\
\text { al. }\end{array}$ & 29 & Male & 300 & $\begin{array}{l}1.4 \\
\text { months }\end{array}$ & Death & NA & - & NA & NA \\
\hline [30] & 2003 & Pan et al. & 58 & Male & 250 & 5 days & Survived & Yes & Yes & PE 2 years prior & No \\
\hline [31] & 2003 & $\begin{array}{l}\text { Selten and } \\
\text { Büller }\end{array}$ & 28 & Male & 400 & 10 days & Survived & NA & No & NA & NA \\
\hline [32] & 2003 & Yang et al & 31 & Male & 100 & 2 months & Death & No & - & No & No \\
\hline [33] & 2004 & Farah et al. & 47 & Female & 300 & 26 months & Death & Yes & - & Anemia & Paroxetine \\
\hline [34] & 2006 & $\begin{array}{l}\text { O'Luanaigh et } \\
\text { al. }\end{array}$ & 52 & Male & 400 & $\begin{array}{l}9.6 \\
\text { months }\end{array}$ & Survived & Yes & Yes & No & No \\
\hline [35] & 2008 & Srihari et al. & 45 & Male & NA & 6 months & Survived & Yes & No & Heavy smoker & No \\
\hline [36] & 2008 & Vayá et al. & 56 & Male & 125 & 2 months & Survived & Yes & NA & $\begin{array}{l}\text { Prothrombin } \\
\text { G20210A }\end{array}$ & NA \\
\hline
\end{tabular}




\section{Cureus}

\begin{tabular}{|c|c|c|c|c|c|c|c|c|c|c|c|}
\hline \multicolumn{12}{|c|}{ mutation carrier } \\
\hline [37] & 2009 & Yeh and Lee & 51 & Female & 300 & 15 days & Survived & Yes & Yes & $\begin{array}{l}\text { Alcohol abuse, } \\
\text { HT, } \\
\text { hyperlipidemia, } \\
\text { heavy smoker, } \\
\text { thyroiditis }\end{array}$ & $\begin{array}{l}\text { Nicotine gum, lithium, } \\
\text { olanzapine, valproic acid, } \\
\text { octreotide, } \\
\text { atropine/diphenoxylate, } \\
\text { cholestyramine, tolterodine, } \\
\text { levothyroxine, metoprolol } \\
\text { tartrate }\end{array}$ \\
\hline [38] & 2009 & $\begin{array}{l}\text { UI-Haq and } \\
\text { Holland }\end{array}$ & 41 & Female & 450 & 5 months & Death & Yes & - & No & $\begin{array}{l}\text { Lithium, zopiclone, } \\
\text { escitalopram, chlorpromazine, } \\
\text { and risperidone }\end{array}$ \\
\hline [38] & 2009 & $\begin{array}{l}\text { Ul-Haq and } \\
\text { Holland }\end{array}$ & 64 & Female & 200 & 21 days & Survived & Yes & Yes & No & NA \\
\hline [38] & 2009 & $\begin{array}{l}\text { Ul-Haq and } \\
\text { Holland }\end{array}$ & 50 & Male & 500 & 4 months & Survived & Yes & Yes & No & $\begin{array}{l}\text { Amisulpride, mirtazapine, } \\
\text { procyclidine }\end{array}$ \\
\hline [39] & 2011 & $\begin{array}{l}\text { Joksovic and } \\
\text { Chiles }\end{array}$ & 52 & Male & 300 & 17 days & Survived & Yes & Yes & $\begin{array}{l}\text { Mild obesity, } \\
\text { hyperlipidemia, } \\
\text { HT, and BPH }\end{array}$ & $\begin{array}{l}\text { Divalproex sodium, } \\
\text { perphenazine, risperidone, } \\
\text { simvastatin, furosemide, } \\
\text { finasteride, tamsulosin }\end{array}$ \\
\hline [40] & 2011 & Tripp & 58 & Female & 175 & $\begin{array}{l}1.4 \\
\text { months }\end{array}$ & Survived & Yes & NA & $\begin{array}{l}\text { Pneumonia one } \\
\text { week prior }\end{array}$ & $\begin{array}{l}\text { Quetiapine, moxifoxacin, } \\
\text { ibuprophen, acetaminophen, } \\
\text { alendronate }\end{array}$ \\
\hline [40] & 2011 & Tripp & 30 & Male & 700 & 3 months & Survived & Yes & No & $\begin{array}{l}\text { Sickle cell } \\
\text { disease, VTE at } \\
12 \text { years old, } \\
\text { smoker }\end{array}$ & No \\
\hline [40] & 2011 & Tripp & 63 & Female & 200 & 22 days & Survived & Yes & No & $\begin{array}{l}\text { Smoker, HT, } \\
\text { asthma, } \\
\text { osteoarthritis, } \\
\text { overweight (BMI } \\
\text { 29.1) }\end{array}$ & $\begin{array}{l}\text { Aspirin, haloperidol, } \\
\text { benztropine, famotidine, } \\
\text { clonidine }\end{array}$ \\
\hline [41] & 2012 & $\begin{array}{l}\text { Suljemanpasic } \\
\text { and Fisekovic }\end{array}$ & 56 & Female & 400 & NA & NA & Yes & NA & $\begin{array}{l}\text { Obesity, } \mathrm{HT} \text {, } \\
\text { hyperlipidemia }\end{array}$ & $\begin{array}{l}\text { Chlorpromazine, haloperidol, } \\
\text { haloperidol decanoate }\end{array}$ \\
\hline [42] & 2013 & Chate et al. & 39 & Male & 150 & $\begin{array}{l}8.6 \\
\text { months }\end{array}$ & Survived & No & Yes & No & No \\
\hline [43] & 2013 & Munoli et al. & 34 & Male & 50 & 84 months & Survived & No & Yes & No & No \\
\hline [44] & 2013 & Hu et al. & 22 & Male & 500 & 24 months & Death & No & - & No & No \\
\hline [45] & 2014 & $\begin{array}{l}\text { Schmidinger } \\
\text { and Hofer }\end{array}$ & 63 & Male & 50 & 14 days & Survived & Yes & Yes & $\begin{array}{l}\text { Alcohol and } \\
\text { benzodiazepines } \\
\text { dependence, } \\
\text { hepatic } \\
\text { steatosis, } \\
\text { overweight (BMI } \\
\text { 29.03) }\end{array}$ & $\begin{array}{l}\text { Lorazepam, gabapentin, } \\
\text { levofloxacin }\end{array}$ \\
\hline [46] & 2015 & $\begin{array}{l}\text { Marinkovic } \\
\text { and Rancic }\end{array}$ & 26 & Female & NA & $\begin{array}{l}13.2 \\
\text { months }\end{array}$ & Death & Yes & - & Postpartum & $\begin{array}{l}\text { Haloperidol, lamotrigin, } \\
\text { diazepam, temazepam }\end{array}$ \\
\hline [47] & 2016 & Goh and John & 31 & Female & 300 & 18 days & Survived & Yes & No & $\begin{array}{l}\text { Obese, smoker, } \\
\text { poor mobility }\end{array}$ & No \\
\hline [48] & 2018 & Li et al. & 62 & Male & 75 & 1 month & Death & Yes & - & $\begin{array}{l}\text { Type } 2 \mathrm{DM} \text {, acid } \\
\text { reflux, tobacco, } \\
\text { and cannabis } \\
\text { use every day }\end{array}$ & No \\
\hline [49] & 2020 & Waters et al. & 56 & Male & 350 & 20 days & Survived & Yes & No & $\begin{array}{l}\text { HT, BPH, type } 2 \\
\text { DM, obese (BMI } \\
\left.30 \mathrm{~kg} / \mathrm{m}^{2}\right)\end{array}$ & Significant polypharmacy \\
\hline
\end{tabular}

TABLE 1: Clozapine-related VTE

BMI: body mass index; BPH: benign prostatic hyperplasia; DM: diabetes mellitus; HT: hypertension; NA: not available; PE: pulmonary embolism; VTE: venous thromboembolism

\section{Age}

In our review, the mean age was 42.92 years $(S D=13)$ (Table 1). In $23(54.76 \%)$ case reports, patients were 40 years old or more. According to Gami et al., antipsychotic agents are associated with VTE in the elderly, and Letmaier et al. reported that patients aged 65 and older with mood disorders have higher VTE incidence and 


\section{Cureus}

concluded that clinicians should consider antipsychotic exposure as a risk factor for VTE in this population $[13,14]$. In contrast, Keijer et al. conducted a study including 111,818 patients aged 60 or older who were on antipsychotic treatment and found no evidence suggesting higher VTE risk than nonusers [15]. According to the American Heart Association (AHA), being 40 years old raises the probability of a VTE, and this risk doubles with each decade [8], independent of antipsychotic use.

\section{Sex}

In our review, there were 12 (28.57\%) females and 30 (71.43\%) males, showing an increased incidence in male antipsychotic users rather than female users (Table 1 ). These findings are similar to those of previous reviews which found between $63.3 \%$ and $75 \%$ of patients were males $[9,12,16]$. In a meta-analysis that included a total of 31,514,226 subjects from 22 studies, Dai et al. observed patients taking first- and secondgeneration antipsychotics [17]. These patients were at a higher risk of VTE than those who were not prescribed antipsychotics, and females taking antipsychotics had a higher risk of PE than males [17]. In the same study, the authors reported that clozapine users have significantly increased VTE risk [17].

\section{Comorbidities and risk factors for venous thromboembolism}

Out of the 42 case reports, 15 did not report patient comorbidities (Table 1 ). Out of the remaining 27 reports that did, 19 (70.37\%) patients had one or more comorbidities and eight (29.63\%) patients did not have any comorbidities. Out of the 19 patients who had comorbidities, 10 (52.63\%) had comorbidities that are described as risk factors for VTE by the AHA (mutations associated with blood clotting, obesity, previous thrombotic events, postpartum) (Table 2) [8]. When describing risk factors for VTE, including age, we could not find information in 10 case reports; of the remaining 32 reports, only four $(12.5 \%)$ had no reported risk factors for VTE, while 28 (87.5\%) reported risk factors.

\begin{tabular}{|c|c|}
\hline Risk factor & Observation \\
\hline \multicolumn{2}{|c|}{ Major surgery (general or orthopedic) } \\
\hline \multicolumn{2}{|l|}{ Low extremity paralysis } \\
\hline \multicolumn{2}{|c|}{ Fracture of long bones, hip, or pelvis } \\
\hline \multicolumn{2}{|l|}{ Multiple trauma } \\
\hline Cancer & Chemotherapy and surgery further increase the risk \\
\hline \multicolumn{2}{|l|}{ Prior vite } \\
\hline Age & $>40$-year-olds are at a higher risk. Risk doubles with each decade \\
\hline Obesity & Two times the risk as people with normal weight. The higher the weight, the higher the risk \\
\hline \multicolumn{2}{|l|}{ Immobility } \\
\hline \multicolumn{2}{|c|}{ Oral contraceptives or estrogen therapy } \\
\hline Family history of VTE & Especially in first-degree relatives \\
\hline \multicolumn{2}{|l|}{ Sedentarism } \\
\hline \multicolumn{2}{|c|}{ Genetic blood conditions that affect clotting } \\
\hline Pregnancy and postpartum & , obesity, older maternal age, and c \\
\hline
\end{tabular}

TABLE 2: Risk factors for VTE.

VTE: venous thromboembolism

According to Ronaldson, patients with mental illnesses usually have risk factors for VTE; however, it is arguable whether VTE is attributable to the pharmacological properties of clozapine or the risk factors of clozapine recipients [18]. Till and Silva reported a case where clozapine was successfully administered in a patient with a previous myocardial infarction and PE [19]. After 94 days of initiating clozapine, the patient's seclusion was terminated after 1,046 days [19]. The most appropriate attitude toward a psychiatric patient treated with clozapine is not to withdraw the medication and switch to another option but to manage the risk factors predisposing to cardiovascular disease and work as a multidisciplinary group $[18,19]$.

\section{Dose}

In our review, two case reports did not report dosage (Table 1). Of the remaining 40 , the mean dose was $285.62 \mathrm{mg}$, with $50 \mathrm{mg}$ being the lowest and $700 \mathrm{mg}$ the highest dose, similar to the findings of Poudyal and Lohani [9]. According to Subramanian et al., doses of $300 \mathrm{mg}$ or less per day are considered low, and doses $>300 \mathrm{mg}$ per day are considered high [20]. Out of these 40 patients, $19(47.5 \%)$ had a low dose (>300 $\mathrm{mg}$ ) and $21(52.5 \%)$ had a high dose (300 mg or more), with a similar distribution. Some studies concluded that most antipsychotic-related VTE appears to be dose-dependent, but no specific dose threshold has been established for clozapine users [11,21]. In contrast to these findings, Kleijer et al. did not find any association between dosage and VTE, and Sarvaiya et al. showed that VTE related to clozapine treatment appears to be dose-independent $[15,16]$.

\section{Time of onset}


In our review, three case reports did not specify when VTE occurred regarding the time of clozapine treatment. Out of the other 39 cases, 28 (71.8\%) occurred within the first six months of treatment, and the remaining 11 (28.2\%) occurred after six months of treatment (Table 1 ). The mean time of onset was 7.49 months, with the earliest event reported on day three and the latest at 84 months of use. These findings are consistent with those of Sarvaiya et al. [16]. In the case report by Sackey et al., the patient had a prescription of $125 \mathrm{mg}$, which was well tolerated, but he took five $100 \mathrm{mg}$ tablets instead of five $25 \mathrm{mg}$ tablets for three days before the event occurred [11]. It may suggest that higher doses have a higher risk of developing VTE.

According to Ronaldson, therapy onset with an antipsychotic in the previous 24 months was associated with a 32\% increased risk for VTE in antipsychotic users, and in the first three months of therapy, the risk was doubled compared to non-users [18]. She stated that among those initiated on clozapine, 16 per 1,000 developed VTE, and those initiated on other antipsychotics developed VTE in 20 per 1,000 patients [18]. Wilkowska et al. reported that the approximate incidence of VTE among antipsychotic users is 4/1,000 in all age groups and 10/10,000 in patients older than 65 years after the first year of treatment [22]. Jönsson et al. observed that the risk is especially relevant in the first three months of treatment onset, suggesting that the medication itself is a more significant risk factor than the underlying disease [6].

\section{Other medication and concomitant antipsychotic use}

Out of the 42 cases, seven did not report on other medications (Table 1). Of the remaining 35 cases, 24 (68.57\%) patients took other medications, while 11 (31.43\%) did not. Among these 35 patients, 17 (48.57\%) had polypharmacy, taking three or more medications at VTE onset, and 21 (60\%) were taking another antipsychotic concomitantly at VTE onset. First and second-generation antipsychotics have been related to VTE $[6,13,18]$. It is difficult to ascertain which antipsychotic has the most substantial relationship with a thrombotic event in a patient taking more than one antipsychotic that has been related to VTE.

\section{Outcome and discontinuation of clozapine}

Out of the 42 case reports, two did not specify the patient's outcome (Table 1). Of the remaining 40 cases, 27 (67.5\%) patients survived, while 13 (32.5\%) died. Studies have reported mortality rates of $26.21-41.66 \%$ $[9,12,16]$. Sarvaiya et al. reported that clozapine doses were similar in the group who died and the group who survived [16]. Of the 27 patients reported to survive in our case series, seven did not specify if the treatment was continued or discontinued. Of the 20 reports for which we had the information, we observed that clozapine was discontinued in $12(60 \%)$ cases and continued in eight (40\%). Interestingly, we can observe that in the last five years, the therapeutic behavior has changed as most of the earlier cases had it discontinued and the recent ones have continued with the treatment (Table 1 ).

Some authors recommend stopping the treatment if a VTE is suspected in a clozapine user [6,12]. Others have suggested prophylactic antithrombotic treatment for patients who have other risk factors for developing VTE [6]. The use of prophylaxis is controversial; in a study, Therasse et al. concluded that DVT incidence was not low despite prophylaxis in psychiatric patients [23]. Another study found that not using anticoagulants was not associated with an increased risk of VTE [24]. Verdoux et al. suggested that discontinuation may be justified in case of VTE recurrence [25].

Managing individual patient risk factors can modify VTE risk in clozapine takers, and continuation versus discontinuation after a PE event should be decided after considering each patient's risk factors, benefits, and disadvantages of continuation $[13,16]$. We found similar opinions in studies by Ronaldson and Till and Silva, who suggested multidisciplinary teamwork $[18,19]$.

\section{Limitations}

Findings from our study depend on the methodological quality of each case report. Furthermore, our outcomes may be limited by missing or incomplete data. There were limited data on patients who continued clozapine use after having a VTE regarding new events. We only included English, Spanish, and French articles for our search; therefore, other case reports may not be included in our study. The lack of a systematic research strategy is also a potential limitation.

\section{Conclusions}

Clozapine has proven to be highly effective in the treatment of resistant schizophrenia. VTE occurs at a wide dose range and more extensive studies should be performed to assess if it is a dose-dependent or independent event. VTE onset appears to be higher during the first six months of treatment. A considerable number of patients prescribed clozapine have comorbidities and at least one risk factor for VTE. Many patients on clozapine also take other medications, including other antipsychotics, that have been related to VTE. Discontinuation of clozapine after VTE appears to have diminished in the last years. It is essential to consider the risks and benefits of clozapine and work as a multidisciplinary group before making decisions, considering that, often, clozapine is the best option for a patient to have a better quality of life. Knowing that VTE is a potentially lethal event, it would be recommended to direct more extensive prospective cohort studies to elucidate the actual relationship so that multidisciplinary teams can write guidelines regarding decision-making on clozapine discontinuation and thromboprophylaxis.

\section{Additional Information \\ Disclosures}

Conflicts of interest: In compliance with the ICMJE uniform disclosure form, all authors declare the following: Payment/services info: All authors have declared that no financial support was received from any organization for the submitted work. Financial relationships: All authors have declared that they have no financial relationships at present or within the previous three years with any organizations that might have an interest in the submitted work. Other relationships: All authors have declared that there are no other relationships or activities that could appear to have influenced the submitted work. 


\section{References}

1. World Health Organization. Newsroom: Schizophrenia. (2019). Accessed: October 30, 2020: https://www.who.int/news-room/fact-sheets/detail/schizophrenia.

2. Meyer JM: Pharmacotherapy of psychosis and mania. Goodman \& Gilman's: The Pharmacological Basis of Therapeutics. Brunton LL, Chabner BA, Knollmann BC (ed): McGraw-Hill, New York, NY; 2012. 1:422-8.

3. Shivakumar K, Amanullah S, Shivakumar R, Saroka K, Rouleau N, Murugan NI: The role of clozapine in treatment-resistant schizophrenia. Complex Clinical Conundrums in Psychiatry: From Theory to Clinical Management. Shivakumar K, Amanullah S (ed): Springer, Cham, Switzerland; 2018. 1:115-22. 10.1007/9783-319-70311-4

4. De Fazio P, Gaetano R, Caroleo M, et al.: Rare and very rare adverse effects of clozapine . Neuropsychiatr Dis Treat. 2015, 11:1995-2003. 10.2147/NDT.S83989

5. Goldhaber SZ: Deep vein thrombosis and pulmonary thrombombolism. Harrison's Principles of Internal Medicine. Jameson JL, Fauci A, Kasper D, Hauser SL, Longo D, Loscalzo J (ed): McGraw-Hill, New York, NY; 2012. 2:2170-7.

6. Jönsson AK, Schill J, Olsson H, Spigset O, Hägg S: Venous thromboembolism during treatment with antipsychotics: a review of current evidence. CNS Drugs. 2018, 32:47-64. 10.1007/s40263-018-0495-7

7. Goldhaber SZ: Deep venous thrombosis and pulmonary thromboembolism . Harrison's Principles of Internal Medicine. Kasper D, Fauci A, Hauser S, Longo D, Jameson JL, Loscalzo J (ed): McGraw-Hill, New York, NY; 2015. 2:1631-7.

8. American Heart Association: risk factors for venous thromboembolism . (2017). Accessed: October 30, 2020: https://www.heart.org/en/health-topics/venous-thromboembolism/risk-factors-for-venousthromboembolism-vte.

9. Poudyal R, Lohani S: Clozapine associated pulmonary embolism: systematic review . J Community Hosp Intern Med Perspect. 2019, 9:300-4. 10.1080/20009666.2019.1627848

10. Tseng WT, Huang TL: Excited catatonia in a patient with fatal pulmonary embolism and a successful treatment strategy. BMC Psychiatry. 2018, 18:342. 10.1186/s12888-018-1925-2

11. Sackey B, Miller LJ, Davis MC: Possible clozapine overdose-associated thromboembolic event. J Clin Psychopharmacol. 2017, 37:364-6. 10.1097/JCP.0000000000000706

12. Hägg S, Bate A, Stahl M, Spigset O: Associations between venous thromboembolism and antipsychotics. A study of the WHO database of adverse drug reactions. Drug Saf. 2008, 31:685-94. 10.2165/00002018200831080-00005

13. Gami RK, Mishra P, Sedlak T: Pulmonary embolism and clozapine use: a case report and literature review . Psychosomatics. 2017, 58:203-8. 10.1016/j.psym.2016.11.004

14. Letmaier M, Grohmann R, Kren C, et al.: Venous thromboembolism during treatment with antipsychotics: results of a drug surveillance programme. World J Biol Psychiatry. 2018, 19:175-86. 10.1080/15622975.2017.1285048

15. Kleijer BC, Heerdink ER, Egberts TC, Jansen PA, van Marum RJ: Antipsychotic drug use and the risk of venous thromboembolism in elderly patients. J Clin Psychopharmacol. 2010, 30:526-30. 10.1097/JCP.0b013e3181f0e87d

16. Sarvaiya N, Lapitskaya Y, Dima L, Manu P: Clozapine-associated pulmonary embolism: a high-mortality, dose-independent and early-onset adverse effect. Am J Ther. 2018, 25:e434-8. 10.1097/MJT.0000000000000806

17. Dai L, Zuo Q, Chen F, Chen L, Shen Y: The association and influencing factors between antipsychotics exposure and the risk of VTE and PE: a systematic review and meta-analysis. Curr Drug Targets. 2020, 21:930-42. 10.2174/1389450121666200422084414

18. Ronaldson KJ: Cardiovascular disease in clozapine-treated patients: evidence, mechanisms and management. CNS Drugs. 2017, 31:777-95. 10.1007/s40263-017-0461-9

19. Till A, Silva E: A case report of the successful administration of clozapine in the face of myocardial infarction, pulmonary embolism and hyperlipidaemia resulting in the termination of long-term seclusion. BMC Psychiatry. 2019, 19:37. 10.1186/s12888-018-2001-7

20. Subramanian S, Völlm BA, Huband N: Clozapine dose for schizophrenia. Cochrane Database Syst Rev. 2017, 6:CD009555. 10.1002/14651858.CD009555.pub2

21. Ogłodek EA, Just MJ, Grzesińska AD, Araszkiewicz A, Szromek AR: The impact of antipsychotics as a risk factor for thromboembolism. Pharmacol Rep. 2018, 70:533-9. 10.1016/j.pharep.2017.12.003

22. Wilkowska A, Kujawska-Danecka H, Hajduk A: Risk and prophylaxis of venous thromboembolism in hospitalized psychiatric patients. A review. Psychiatr Pol. 2018, 52:421-35. 10.12740/PP/78891

23. Therasse A, Persano HL, Ventura AD, Tecco JM: Incidence and prevention of deep vein thrombosis in restrained psychiatric patients. Psychiatr Danub. 2018, 30:412-4.

24. Ishida T, Sakurai H, Watanabe K, Iwashita S, Mimura M, Uchida H: Incidence of deep vein thrombosis in catatonic patients: a chart review. Psychiatry Res. 2016, 241:61-5. 10.1016/j.psychres.2016.04.105

25. Verdoux H, Quiles C, de Leon J: Clinical determinants of fever in clozapine users and implications for treatment management: a narrative review. Schizophr Res. 2019, 211:1-9. 10.1016/j.schres.2019.07.040

26. Coodin S, Ballegeer T: Clozapine therapy and pulmonary embolism. Can J Psychiatry. 2000, 45:395.

27. Suttmann I, Dittert S, Landgraf R, Schulze J, Folwaczny C: Clozapine and sudden death. Lancet. 2000, 355:842-3. 10.1016/s0140-6736(05)72453-3

28. Maynes D: Bilateral pulmonary embolism in a patient on clozapine therapy . Can J Psychiatry. 2000, 45:2967.

29. Ihde-Scholl T, Rolli ML, Jefferson JW: Clozapine and pulmonary embolus. Am J Psychiatry. 2001, 158:499500. 10.1176/appi.ajp.158.3.499

30. Pan R, John V, Hägg S: Clozapine and pulmonary embolism. Acta Psychiatr Scand. 2003, 108:76-7. 10.1034/j.1600-0447.2003.00073.x

31. Selten JP, Büller H: Clozapine and venous thromboembolism: further evidence. J Clin Psychiatry. 2003, 64:609.

32. Yang TY, Chung KJ, Huang TL, Kung CT: Massive pulmonary embolism in a young patient on clozapine therapy. J Emerg Med. 2004, 27:27-9. 10.1016/j.jemermed.2003.12.027

33. Farah RE, Makhoul NM, Farah RE, Shai MD: Fatal venous thromboembolism associated with antipsychotic therapy. Ann Pharmacother. 2004, 38:1435-8. 10.1345/aph.1E021

34. O'Luanaigh C, Scully P: An Irish case of pulmonary emboli secondary to clozapine therapy . Ir J Psychol Med. 2006, 23:36-7. 10.1017/S0790966700009472

35. Srihari VH, Lee TW: Pulmonary embolism in a patient taking clozapine . BMJ. 2008, 336:1499-501. 10.1136/bmj.39545.690613.47

36. Vayá A, Lopez M, Plumé G, Ribes J: Upper-extremity deep vein thrombosis in a patient on clozapine therapy carrying the prothrombin G20210A mutation. Pathophysiol Haemost Thromb. 2008, 36:105-7. $10.1159 / 000173731$

37. Yeh J, Lee A: Clozapine-induced pulmonary embolism: a case report and literature review . Hosp Pharm. 2009, 44:36-40.10.1310/hpj4401-36

38. Ul-Haq A, Holland E: Pulmonary embolism secondary to clozapine therapy. Ir J Psychol Med. 2009, 26:149- 


\section{Cureus}

50. 10.1017/S0790966700000483

39. Joksovic PM, Chiles C: A case of cardiac arrest and pulmonary embolism after clozapine titration . Prim Care Companion CNS Disord. 2011, 13:PCC.10101062. 10.4088/PCC.10101062

40. Tripp AC: Nonfatal pulmonary embolus associated with clozapine treatment: a case series . Gen Hosp Psychiatry. 2011, 33:85.e5-6. 10.1016/i.genhosppsych.2010.11.010

41. Sulejmanpasic GA, Fisekovic S: Pulmonary thromboembolism induced by clozapine and high doses of firstgeneration antipsychotics. Eur Psychiatry. 2012, 27:1. 10.1016/S0924-9338(12)75363-4

42. Chate S, Patted S, Nayak R, Patil N, Pandurangi A: Pulmonary thromboembolism associated with clozapine J Neuropsychiatry Clin Neurosci. 2013, 25:E3-6. 10.1176/appi.neuropsych.12080201

43. Munoli RN, Praharaj SK, Bhat SM: Clozapine-induced recurrent pulmonary thromboembolism. I Neuropsychiatry Clin Neurosci. 2013, 25:E50-1. 10.1176/appi.neuropsych.12070186

44. Hu Q, Zhang C, Zhu S: Fatal multisystem venous thrombosis associated with clozapine. J Clin Psychopharmacol. 2013, 33:256-8. 10.1097/JCP.0b013e318285683b

45. Schmidinger S, Hofer A: Pulmonary embolism and aspiration pneumonia after reexposure to clozapine: pulmonary adverse effects of clozapine. J Clin Psychopharmacol. 2014, 34:385-7.

10.1097/JCP.0000000000000124

46. Marinkovic N, Rancic D: Pulmonary thromboembolism and sudden death in psychiatric patients - two cases report. Vojnosanit Pregl. 2017, 74:173-6. 10.2298/VSP150325164M

47. Goh JG, John AP: A case report of clozapine continuation after pulmonary embolism in the context of other risk factors for thromboembolism. Aust N Z J Psychiatry. 2016, 50:1205-6. 10.1177/0004867416641493

48. Li KJ, Gurrera RJ, Delisi LE: Potentially fatal outcomes associated with clozapine. Schizophr Res. 2018, 199:386-9. 10.1016/.j.schres.2018.02.058

49. Waters K, Goodwin H, Morrow G: Clozapine-induced pulmonary embolism in a patient with minimal preexisting risk factors. J Am Pharm Assoc (2003). 2021, 61:e53-6. 10.1016/j.japh.2020.07.017 